\title{
Macroeconomic trouble and policy challenges in the wake of the financial bust
}

ANGEL ASENSIO*

Contrasting with the 1929 great crisis, authorities intervened forcefully in 2008 to stop the disintegration of the financial system. Governments and central banks then sought to revise the prudential regulation in depth. It would be optimistic, however, to believe that prudential measures, alone, could deliver full economic recovery, at least in the countries that had been involved in the financial turmoil. Indeed, the collapse of the "state of confidence" and the negative effects of private debts on consumption and investment decisions have fed depressive forces and policy challenges which could hold for a while, even once the financial sector is made safe. On the one hand, the economic slowdown and the direct and indirect assistance provided by the governments to the private sectors are having a heavy impact on public finances, meanwhile, on the other hand, the massive amounts of money which artificially inflated the prices of housing and financial products could produce inflationary pressures in the post-crisis period, unless a new assets bubble is allowed for. Authorities could therefore be facing high unemployment in a damaged context of public deficits and inflationary pressures. The paper aims at discussing these new challenges. The inadequacy of inflation targets and fiscal orthodoxy in a depressed economy is emphasized, and the outlines of a Post Keynesian alternative policy are examined.

Keywords: depression; financial crisis; inflation; macroeconomic policy.

JEL Classification: B22; E00; E10; E12; E13; E30; E31; E60.

* CEPN - Université Paris 13. E-mail: asensio.angel@univ-paris13.fr. I would like to thank two anonymous referees of the Brazilian Journal of Political Economy for their useful comments. Submitted: May 2010; Approved: September 2010. 


\section{INTRODUCTION}

Contrasting with the 1929 great crisis, authorities intervened forcefully in 2008 to stop the disintegration of the financial system. This was obtained by means of massive liquidity pumping and state guarantees over private assets which eventually reintroduced some confidence within the financial system, and stopped the process of depreciation of assets. A salient feature at the end of 2009 was the rapid recovery in the financial sector as compared with the lasting difficulties in the goods and labor markets. It was as if the pre-crisis financial euphoria had come back, but in a depressed context, at least in the countries that had been involved in the financial turmoil. Such a discrepancy raises the nagging question of whether and how a depressed economic system could feed such high financial returns. In other words: did the authorities' intervention fix the bubble and allow assets markets to start inflating again?

It is not clear whether the markets practices are going to be severely constrained, but if the change in regulation principles is not constraining enough, old practices will hardly disappear spontaneously, so that a new bubble could hide difficulties one more time, until the next crisis. Of course, this should not be considered a safe solution for the authorities' capacity to save the financial system and support the whole economy has been severely weakened. Therefore authorities could hardly provide such a massive support again before having recovered, the knowledge of which would, in case of a new financial collapse, produce much more panics and catastrophic outcomes than in the previous case. Hence, although such a new bubble scenario looks plausible, this paper concentrates on the case where, possibly after a future replica, safer financial regulation principles are eventually implemented so that the excess liquidity starts fuelling inflationary pressures in real estate, durables and speculative goods, instead of financial products ${ }^{1}$. This scenario involves new challenges in terms of monetary and fiscal policy, for inflationary pressures in this case are concomitant of serious public finance deterioration, so that authorities are tempted to implement restrictive policies in a context of fragile economic recovery.

The paper first argues that, although depressive forces look to have been successfully stopped, there is little hope that the economies involved in the financial turmoil recover spontaneously the pre-crisis path. Then it is argued that monetary

\footnotetext{
${ }^{1}$ Post Keynesians refer to this type of inflation as commodity or capital inflation, which is different from income inflation. Income inflation "is associated with the rise in the flow-supply prices at any given level of output flow in forward markets - that is, the money costs of production associated with each unit of goods produced" (Davidson, 2006, p. 694). Davidson argues that commodity or capital inflation "can easily be avoided if there is some institution that is not motivated by self-interest but, instead, maintains a 'buffer stock' to prevent unforeseen changes in spot demand and supply from inducing significant spot price movements". However, in certain circumstances, commodity and capital inflation may transmit to the flow supply price, thereby feeding income inflation (see Asensio, 2009b), all the more since "buffers stocks" do not exist in all the sectors, although they may exist in strategic sectors, like oil.
} 
and fiscal policies have inherited difficulties in terms of public debt and excess liquidity that tend to induce restrictive responses. Finally, the inadequacy of orthodox monetary and fiscal policies in a context of depressed economies is emphasized and the outlines of an appropriate policy are examined.

\section{SLUGGISH RECOVERY}

The cause of the financial crisis triggered by the subprime episode has been located in the failure of prudential regulation (Davidson, 2008, 2009) ${ }^{2}$, but the necessary palliative which permitted getting out of the financial turmoil (though not to get out of lasting severe difficulties) was an unusual and massive intervention of public institutions aimed at protecting the financial system against complete chaos and the whole economy against much deeper depression. In fact, these defensive reactions (including support to aggregate demand) were not strictly aimed at stimulating the economy, but rather at stopping both the financial system disintegration and the deflationary process. That is, the expected result was obviously not to improve the performances of a safe economic system, but to save a dying patient at all costs, until the cause of the disease starts being dealt with. This is an important point for, although the financial markets and institutions looked much better after such an emergency medication, and although depressive forces looked to have been successfully stopped, there is little hope that the economy recovers spontaneously the pre-crisis path.

The post-crisis growth path will be determined by the aggregate demand dynamism, which itself depends on financing conditions. As regards financial institutions, the memory of the collapse will certainly make banks and non-banks more prudent and selective as far as financing activities are concerned. This will be reinforced, more or less, by the new prudential regulations that are progressively implemented, so that one can reasonably expect some part of the riskier projects, which would have been financed in the pre-crisis euphoric climate, to be rejected in the future. Of course, it is not necessarily a bad thing, unless some projects are unduly rejected as a result of a kind of precautionary principle. Now, even if such a perverse effect can be avoided, it remains that financing conditions will hardly be easier than before the financial turmoil, and should actually be less generous. A memory effect is likely to influence portfolio decisions as well, for the post-crisis balance sheets of private and public financial institutions (including treasuries and central banks) should remain stuffed with lots of toxic assets for a while, so that further financial turmoil cannot be discarded. And such a threat is likely to boost the liquidity preference, people wanting to limit the share of risky assets in their

\footnotetext{
${ }^{2}$ Palley (2009) "traces the roots of the current financial crisis to a faulty U.S. macroeconomic paradigm. One flaw in this paradigm was the neo-liberal growth model adopted after 1980 that relied on debt and asset price inflation to drive demand. [...] Deregulation and financial excess are important parts of the story, but they are not the ultimate cause of the crisis".
} 
portfolio. As a matter of consequence, while the financial turmoil has ended, the long-term interest rates and the required return on equities could remain relatively high as compared with their pre-crisis level. Moreover, in spite of the stocks of reserves banks have accumulated during the rescue episode, bank-credit rates as well could take advantage of the situation and remain relatively high, for banks will be able to sell more credit without reducing their interest rates substantially as far as bonds and non-bank loan rates remain relatively high.

Those worsened financing conditions in turn should make it more difficult for firms and households to maintain the pre-crisis level of expenditures as regards productive investments, housing and durable credit-financed consumption good, all the more since household and firms could cut back on their expenses in order to reduce their debt. In addition, a degradation of the expected return on productive investments can also be feared. The inducement to invest should therefore be weakened both because of the sluggishness of the households' demand for goods and because of the weakened "entrepreneurial spirit".

Hence, the illness has not been dealt with yet, and the cure requires both new financial regulations and public support to aggregate demand. As for the new financial regulations, the message seems to have been well understood by authorities, which committed to revise profoundly the rules of the game, at least in 2008-2009 until the markets started showing some resistance against constraining prudential regulation. We will see whether markets practices are going to be deeply constrained or not, but in the meantime, as the emergency measures got to save the patient by providing the private sector with the required liquidity and the required guaranty, both the central banks and governments have accumulated or guaranteed huge amounts of doubtful private assets. And this is likely to harm their capacity to support further the economy subsequently.

\section{BOGGED DOWN MONETARY AND FISCAL POLICIES}

\section{Dealing with public debts in depressed economies}

Public finances use to be severely damaged after a depression, both because of the collapse of fiscal revenues and because of the huge increase in the public expenditures that have been directly and indirectly induced by the support to the financial sector, to private companies and to households (Bank for International Settlements, 2009, pp. 91-115). Fiscal authorities accordingly seems to have a limited room for manoeuvre to counter the sluggish conditions of the private sector recovery (see however the discussion below), for markets tend to raise the risk premium on public debt interest rate for those countries which exhibit strongly deteriorated public accounts and repayment difficulties. As an increased risk premium would deteriorate further the situation and could trigger a dangerous vicious circle, governments in such circumstances are very tempted not to increase expenditures or reduce taxes, thereby renouncing to support the private sector. 
Of course, post-crisis economic recoveries use to alleviate public accounts spontaneously to some extent. However, even in the optimistic case of a rapid return to the pre-crisis growth trajectory combined with a rapid reduction of the budget deficit, the level of the public debt is likely to remain higher than the precrisis one, for the past deficits do weight the debt burden as long as surpluses do not compensate for them. In the less favorable (but very plausible) circumstances where the recovery process spreads over a long period of time, owed to the weak aggregate demand dynamism and the weak public support, the post crisis growth regime could make it still more difficult for governments to balance their budget. This could in turn allow for a growing public debt, as suggested in Figure 1.

Figure 1: One possible vicious circle in a convalescent economy

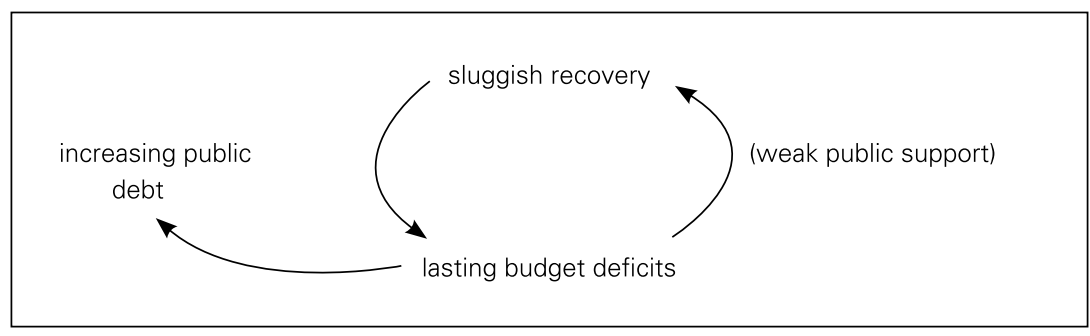

The current context in addition involves a worsening factor. This results from the different kind of government guarantees and purchases of private assets that have been made necessary in order to save the financial sectors, whatever it has operated directly (nationalization, recapitalization, loans...) or indirectly (stateguaranteed bad banks and other ad hoc specialized institutions). Indeed, part of these bad assets have been purchased or guaranteed when the markets lost their bearing in the storm. They are likely to be sealable at a price which will not involve any loss. But there are amounts of either purchased or state guaranteed private debts which will appear to be irrecoverable, or which market price could hardly reach again the level at which they were purchased when some "financial innovations" unduly inflated their value. Hence, unless a new bubble boosts again these assets value, public finances are likely to be affected by the depreciation of the stock of bad debts they purchased ${ }^{3}$. The problem is all the more detrimental since the corresponding amount of public money was not spent in any welfare-improving public goods or services. It was spent in depreciated assets, part of which will probably not bring back the money they have cost. And as no supplementary taxes or borrowed resources have been collected in order to pay for these assets, they simply contribute to make the public debt heavier ${ }^{4}$. Which finally makes the pernicious process illustrated in Figure, 1 more difficult to get round.

\footnotetext{
${ }^{3}$ See International Monetary Fund, 2009.

${ }^{4}$ For a quantitative appraisal see the International Monetary Fund Staff Position Note SPN/09/13. According to the Laeven and Valencia $(2008$, p. 24) database on systemic banking crises, "Fiscal costs,
} 


\section{Bubbles and excess money}

Central banks also accepted bad collaterals in exchange of the liquidity which has been pumped into the banking sector. The central bank balance-sheets accordingly increased dramatically (Bank for International Settlements, 2009, pp. 91110.). Optimistic views assert that one should not worry about the toxic collaterals central banks have been forced to buy in order to rescue the banking system. According to Davidson (2009),

"These assets are called 'toxic' not because they are worthless in the sense that they may never generate a future cash inflow, they are 'toxic' because the market doesn't know how to evaluate them. [...] we are going to make a profit because over the long run enough people are going to continue to pay their mortgages or whatever backs these exotic financial assets so we will make a profit on it, which says that these things have a value, but we don't know what that value is."

Horn $(2008$, p. 6) however reported that

"[...] it is not guaranteed that the ECB can sell them with profits. The ECB takes this into account to some extent by applying a uniform haircut add-on between $5 \%$ and $10 \%$ and other down payments."

Anyway, those possible losses are the tree which hides the wood. Even if the central banks were able to withdraw all the liquidities they pumped into the banking sector during the rescue episode ${ }^{5}$, it remains that banking systems, especially in the U.S., created huge amounts of money to finance private purchases (notably house purchases and real estate investments) in exchange of repay commitments that eventually were not honoured, or only partially. Hence, important amounts of bad money had been (endogenously) pumped in exchange of bad debts for a long time when the crisis started. The bubble in the housing sector was obviously fuelled by such an excess credit-money ${ }^{6}$. The massive "securitization" subsequent-

net of recoveries, associated with crisis management can be substantial, averaging about $13.3 \%$ of GDP on average, and can be as high as $55.1 \%$ of GDP. Recoveries of fiscal outlays vary widely as well, with the average recovery rate reaching $18.2 \%$ of gross fiscal costs. While countries that used asset management companies seem to achieve slightly higher recovery rates, the correlation is very small, at about $10 \%$. Finally, output losses (measured as deviations from trend GDP) of systemic banking crises can be large, averaging about $20 \%$ of GDP on average during the first four years of the crisis, and ranging from a low of $0 \%$ to a high of $98 \%$ of GDP".

${ }^{5}$ It might be not that easy in the fragile post-crisis context, because it could be dangerous to put back lots of toxic assets into circulation in order to withdraw liquidity. Horn (2008, pp. 8) statement that "The ECB just has to sell the assets she has bought during the crisis" sounds therefore somewhat optimistic too.

${ }^{6}$ Excess money does not refer here to an excess of the supply over the demand for money, which would 
ly helped to disseminate asset-prices inflation internationally, since the bad quality of the toxic assets was dissimulated, thereby allowing for overvaluation in international markets.

When the bubble burst, and the real value of real and financial assets collapsed, the excess money which still was circulating (since it had not been withdrawn, as part of the related private debts could not be honoured), was first absorbed by a dramatic increase in the demand for liquidity and other secure holdings (quasimoney, low-risk liquid assets, gold...). But, as the new financial regulations were not implemented rapidly and therefore financial product became very attractive again (all the more since authorities had provided state guaranty in order to rescue the financial sector), the asset-prices inflation process started again 7 .

The financial assets overvaluation might continue, or even develop, until another financial collapse stops that unsafe process once again. But let us examine the implications if the financial rules are strongly enough reinforced so that the financial markets become much less attractive. Liquidities in this case would try to make profit from purchases of durable and capital goods, oil, gold... instead of financial assets. It is true that, in normal times where credit-money endogenously finances safe productive investments so that the return on investment which is required to repay the money initially borrowed eventually proves to be sufficient, inflation cannot arise below full employment ${ }^{8}$. In this case, the money inflows and outflows ensure that no excess money circulates in the economy. Now, in troubled times where amounts of credit-money which has been previously created cannot be destroyed by a normal outflow, an excess purchasing power unduly remains in the economy, thereby allowing for an increase in the money value of some goods and real assets (unless a shift in the liquidity preference increases the money demand proportionally). Hence, with respect to the current situation, when the recovery process reaches the pre-crisis level, producers will hardly be able to provide within normal delays the additional amount of goods that the excess amount of money could purchase at previous prices, all the more so as the existing capacity

\footnotetext{
be inconsistent with the Post Keynesian approach to endogenous money, where the money supply sticks to the demand; it refers to the notion of "bad money" as defined above., that is, money that has been provided endogenously but that subsequently has turned out to be in excess because of some counterpart failure.

${ }^{7}$ The financial markets recovery of 2009 is documented for example in International Monetary Fund, 2010, p. 1.

${ }^{8}$ Keynes put forward that below full employment prices use to increase along with the output level (GT, ch. 21, sec. III, p. 295 ss.); but he clearly distinguished this process from "true inflation": "When a further increase in the quantity of effective demand produces no further increase in output and entirely spends itself on an increase in the cost-unit fully proportionate to the increase in effective demand, we have reached a condition which might be appropriately designated as one of true inflation" (GT, p. 303), Notice that in this definition, full employment is a sufficient condition for an effective demand stimulus to produce true inflation, but it is not a necessary condition. As Victoria Chick pointed out, "there is nothing in [The General Theory] which actually impedes understanding of the conjunction of unemployment and inflation" (Chick, 1983, p. 280).
} 
is likely to have suffered during the depression (International Monetary Fund, World Economic Outlook 2009, pp. 31-33)9. A Demand-pull inflation process therefore may very well develop in a context of unemployment, insofar as the precrisis level of unemployment is below full employment ${ }^{10}$,

The magnitude of such inflationary pressures (or the magnitude of the policy measures that could be adopted in order to fight them) depends on the authorities capacity to withdraw the bad money rapidly enough as to offset the decrease of the liquidity preference ${ }^{11}$. There is technically no major problem to withdraw liquidity from the economy, but as stated above, it is not clear at all that such a policy could be implemented without damaging the financial system and the fragile economic recovery. It happens finally that central banks should have to navigate in turbulent water, between repressing inflationary pressures and preserving the financial system stability.

\section{Collectivizing private losses: who is paying the bill?}

As discussed above, the 2008 massive public interventions involved a transfer to the public sector (central banks and governments) of big amounts of private bad debts part of which will probably not be recovered. Also, public deficits were magnified because of the fall in fiscal revenues and induced expenditures. This raises the question of the distribution of the burden of the socialized losses. The answer actually depends on the way authorities decide to deal with the problems mentioned in the previous section.

As regards excess money, insofar as investments in extended capacities require some delay, authorities may decide to let inflation develop temporarily, until the real value of money has depreciated enough, in relation to the amount of unrecoverable debts. This solution preserves the economic activity and employment to the detriment of creditors, whose assets real value depreciate in proportion to the increase in prices. If on the other hand authorities decide not to allow for such a temporary increase in prices, unemployment is likely to be hit, as well as debtors, for interest rates have to go up in order to repress the inflationary pressures.

\footnotetext{
${ }^{9}$ In spite of a $12 \%$ unemployment rate in the UK, Keynes (1937) expressed his concern with possible inflationary pressures owing to the government proposal to finance rearmament partly by means of borrowed money. Today's possible inflationary pressures are related to the fact that the expansion of productive capacity is limited by the necessary delay for capital accumulation of course, not by the allocation of productive resources to the production of arms.

${ }^{10}$ See Asensio (2009b) for a detailed discussion. Note that an excess of money is also a demand-pull inflationary process in the neoclassical view, but it may happen before full employment in the Post Keynesian approach (while it cannot in the neoclassical one). Also, as Post Keynesians use to emphasize, inflation always has a distributive conflict side. In the present case the conflict holds in the incompatible claims for goods that results, at previous prices, from the excess amount of money.

${ }^{11}$ In the Global Finance Stability Report 2009 (pp. 2-5) the International Monetary Fund reported how the 'risk appetite' had increased from April 2009.
} 
As regard public deficits, governments for their part may decide to increase taxes so that fiscal revenues increase enough as to balance the government purchase of unrecoverable private debts and offset the fiscal losses the economic depression has generated. As government purchases of unrecoverable debts do not support economic activity at all, while taxes certainly reduce the private demand for goods and services, this solution eventually puts the burden on redundant people and taxpayers. If on the other hand current taxes do not compensate totally for the unrecoverable debt purchases and fiscal losses (which means an increase in public debt or a decrease in public capital holdings), unemployment rises to a lesser extent, and some inflation develops.

Hence, central banks and governments should be faced with the well known inflation/unemployment dilemma, though with differentiated distributional effects. Notice that the fiscal and monetary responses which might be induced by the process of collectivization of losses per se would hardly support economic activity. It should on the contrary have depressive effects, for even if inflation and budget deficit were preferred, it would only spare restrictive measures such as tax and/or interest rates increases. The collectivization of losses therefore induces either depressive or stagflationary forces.

\section{COMPARING FISCAL ORTHODOXY AND INTERVENTIONISM À LA KEYNES IN THE POST-CRISIS CONTEXT}

\section{Restrictive fiscal policies: the next big threat}

The financial crisis thereby has seriously weakened the central banks and governments capacity to really support a recovery; worse, it started compelling several countries to implement restrictive measures and several others to seriously think about it. The mainstream policy principles indeed recommend a reduction of the public deficit and even a budget surplus aimed at reducing the stock of the public debt, and thereby the sovereign debt risk premium. Such principles could make sense in a safe, full employment economy, as a way to stop the well known vicious circle: budget deficit - increased debt - increased risk premium - budget deficit... But in depressed economies, it is counterproductive to strive to reduce the budget deficit before the economy has recovered his strengths: as authorities become impatient to remove the budget deficit, the recovery becomes more difficult, fiscal revenues go down, inducing more spending cuts, weaker recovery and again less fiscal revenues... Thus, as suggested in Figure 2, a vicious circle may take place instead of restored public finances ${ }^{12}$. Many countries expe-

\footnotetext{
${ }^{12}$ At a national level, external demand may compensate for the depressed domestic demand if the international context is favorable, but such opportunity is much more unlikely to happen in the current international context where restrictive policies tend to become standard.
} 
rienced such pernicious dynamics when they were compelled to implement the so called "stabilization programs".

Figure 2: The danger of spending cuts in a convalescent economy

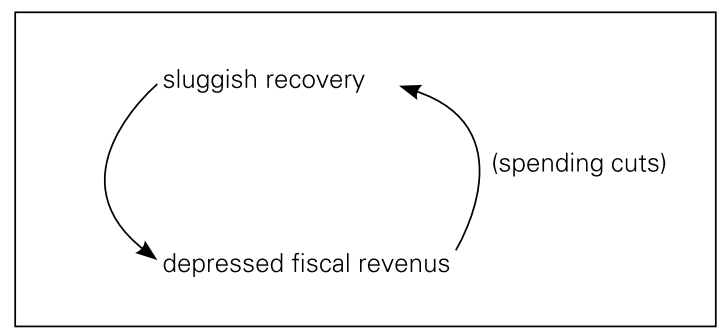

Hence, spending cuts may worry financial markets much more, instead of reassuring them, for markets are aware that increasing idle capacities owed to spending cuts mean lower returns on investments, lower economic growth and possibly higher public deficits. Mainstream recipes could therefore increase the risk premia instead of reducing them. Only when the private aggregate demand engine is firmly launched could prudent cuts have a chance of reducing the public debts. Public debts have been magnified because of the exceptional depression caused by the financial turmoil. They will go down when normal conditions are recovered. If restrictive measures then remained necessary, they would be much weaker, much more bearable and therefore much easier to implement. Politicians must consider that public spending cuts in a period where the social needs for public assistance explode could produce serious troubles and damage further the state of confidence and the whole financial and economic system.

\section{Looking for solutions}

In the first times of a recovery, idle capacities use to allow firms to absorb increases in expected aggregate demand until the economy rejoins approximately the pre-crisis level of activity (or maybe an inferior level since some capacities may have been destroyed during the crisis). In this respect, the public support could be decisive, for it has been argued above that the private sector per se is likely to experiment a weakened "entrepreneurial spirit" in the post-crisis period. What is needed, at least in the most depressed countries (notably in those countries that did implement a timid support during the depressive phase of the crisis, as in Europe), is a public stimulus capable of sustaining the expected aggregate demand until it stands on its own two feet and the confidence in the production viability and profitability is completely restored. Several factors are likely to make expansionary policies much more effective in a depressed system. First, since the public stimulus helps restoring the expected profitability of the private productive investments, it should make the Keynes multiplier higher. Second, the share of the irrecoverable debts is likely to be finally much lower in a context of economic recovery, which reduces the source of 
the troubles. Third, strong economic recoveries induce fiscal revenues which may help governments to socialize private losses without having to increase taxes. Hence, insofar as a fast recovery generates important fiscal revenues, public deficits would not necessarily increase and could even decrease if the initial impact of the public support does not overcome the induced fiscal revenues (Figure 3$)^{13}$.

Figure 3: One possible virtuous circle in a depressed economy

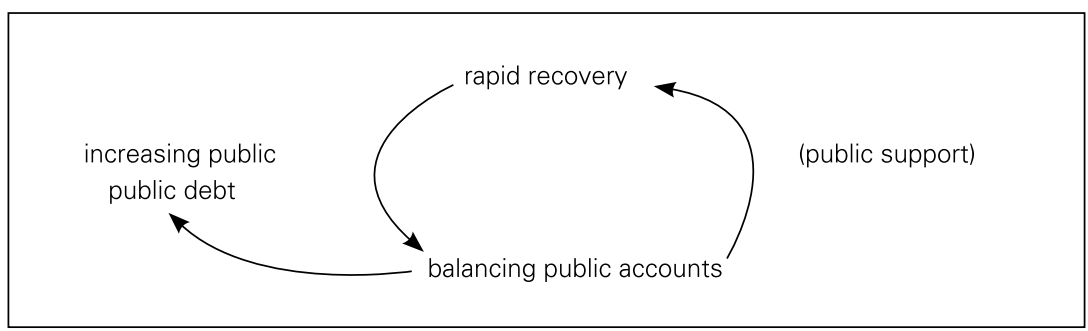

Once the economy is back on the rails, the challenge for authorities, as suggested above, is to escape the depressive / stagflationary forces the collectivization of losses involves. The need then is to favour the extension of aggregate demand and the related productive capacities in relation with the part of the excess money which has not been withdrawn for whatever reason. As the capital accumulation and the raising productive capacity might not be as fast as to cancel inflationary pressures immediately, it might be of interest to consider the possibility for some government agencies to borrow from money holders, and then start progressively financing public investments and fiscal incentives for private investments, spreading expenditures over time so that the productive capacity of capital goods is never overwhelmed ${ }^{14}$.

Central Banks could have a major part in this respect if they got to keep longterm interest rates low enough ${ }^{15}$ so that investment financing is made as cheaper as possible (provided the credit-money finances safe/non inflationary investments of course). The danger would rather be that a restricted credit policy put the burden of past mistakes on current safe economic projects ${ }^{16}$. It is possible nevertheless that

\footnotetext{
${ }^{13}$ Since the purpose is only to boost temporarily the state of affairs private initiatives, the initial deficit is only temporary while the future revenues are likely to persist once the growth trajectory is consolidated.

${ }^{14}$ This amounts to transfer private purchasing power to the future in the spirit of the "deferred pay" Keynes (1940) advocated in order to avoid the inflationary pressures owed to the shortage in productive capacities (since capacities were used in the armament industry instead of the production of goods and services).

${ }^{15}$ This is not assured according to Keynes's theory, for it requires the central bank policy to preserve the markets confidence (see Asensio, 2009a, for a detailed discussion). It might also require some capital controls in an open system.

${ }^{16}$ Interestingly, when there is an excess money that cannot be withdrawn, it is possible to fight the re-
} 
low interest rates per se do not stimulate private investments very much, as investments also depend on the expected return on productive capital. Therefore, it is important that authorities show a determined commitment to engage in measures aimed at supporting private and public investments, especially in the domains where productive capacities are going to be insufficient, so that the expected demand and related profits increase substantially.

Low long-term interest rates also prevent the dynamics of the debt to be unduly boosted ${ }^{17}$. It would be unjustifiable to let those markets which have caused great troubles and deteriorated public finances to decide punitive risk premia on sovereign debts, all the more since it would suffice that central banks commit themselves to refinance public debts at normal rates for the markets calm down. It is the central banks responsability to prevent a situation where governments have no choice but to adopt depressive measures under the markets pressure in a fragile post-crisis context. Remember that public finances become safer as the recovery goes along, provided restrictive policies do not postpone the recovery (which would make the problem worse in the future). At the end of the day, who would approve that the central bank denied support to the government effort in favour of recovery and fragilized people, whereas the private financial sector was bailed out massively?

\section{CONCLUSION}

The first response authorities brought to the financial crisis got to stop the depressive effects on output and employment, but the public support to aggregate demand did not compensate for the private demand slump everywhere, as attested by the severe depression in those countries that have been involved in the financial turmoil. These countries accordingly struggle to reach the pre-crisis utilization of productive resources, for, in the one hand, the dynamism of aggregate demand and the expected profits have been hit lastingly and, in the other hand, macro policies have been facing serious difficulties that reduced their room for manoeuvre. There is accordingly a temptation to implement restrictive policies in spite of the fragile recovery context. This is confining many economies, especially in Europe, in a sluggish growth regime and could soon generate instability in the international monetary system, for it will be tempting to export difficulties by means of a currency competitive devaluations in the country where the internal demand is apathetic.

What is needed, besides a safer financial regulation, differs in the immediate post-crisis recovery period and in the subsequent growth regime. The post-crisis

lated inflationary pressures by means of lower interest rates (and public borrowing for public investments), since inflationary pressures can be considered the result of an insufficient productive capacity.

${ }^{17}$ On the complementary roles of the central bank and the Treasury in managing the public debt and the long term interest rates see Tily (2006, 2007, pp. 201-206). 
recovery calls for a public stimulus capable of sustaining the expected aggregate demand until it stands on its own two feet and the confidence in the production profitability is completely restored. In the current context of depressed economies, this would be much more capable to reinforce banks and firms balance sheets, generate fiscal revenues and reduce social expenditures, and, eventually, to restore public finances and strengthen the economic growth. Afterwards, when the capacity utilization rejoins the pre-crisis level, the need will be to favour the extension of aggregate demand and the related productive capacities in relation with that part of the excess money which has not been withdrawn. In the most depressed economies, combining a low interest rate policy, provided it is possible, with fiscal support would benefit to both the private inducement to invest and the public debt burden, thereby improving the policy effectiveness. It would be much better that countries co-operate so that interest rates differentials and exchanges rates remain under control, but capital controls might be a necessary condition for national authorities having, at least temporarily, the capacity to resist to the market forces. And indeed, although the above discussion concentrates on solutions that come under the national authorities, there is much to develop in terms of international co-operation in order to solve important challenges, like the possibility for China and other emerging countries to change their growth regime from an "export led" to a "consumption-led" one. Insofar as it supposes the possibility for the U.S. and other rich countries to reduce their trade balance deficit, exchange rates agreements certainly should take part of the co-operative process if aggregate demand is to be supported for the world economy as a whole.

\section{REFERENCES}

ASENSIO, A. (2009a) "Between the cup and the lip - Interest rate rules and long-term interest rates management", presented at the conference: 'The political economy of central banking', organized by IEPI-Laurentian U., Toronto, 27-28 May.

ASENSIO, A. (2009b) "Bad money and distributive conflict: is stagflation coming back after the great depression?”, presented at the CEMF (U. of Burgundy)/IEPI (Laurentian U.) $4^{\text {th }}$ bi-annual conference (in collaboration with ADEK) on "The financial and monetary crisis: rethinking economic policies and redefining the architecture and governance of international finance".

BANK FOR INTERNATIONAL SETTLEMENTS (2009) 79th Annual Report, Basel, 29 June.

CHICK, V. (1983) Macroeconomics after Keynes, Cambridge, MA: MIT Press.

DAVIDSON, P. (2006) "Can, or should, a Central Bank inflation target?" Journal of Post Keynesian Economics, 28.

DAVIDSON, P. (2008) "Is the current financial distress caused by the sub prime mortgage crisis a Minsky moment? Or is it the result of attempting to securitize illiquid non commercial mortgage loans?", Journal of Post Keynesian Economics, 30.

DAVIDSON P. (2009) Interview with Paul Davidson, Regarding the Crisis, Mosler Economic Policy Center.

HORN, G.A. (2008) "The rational for or against expanding central bank eligible collateral in times of distress", Briefing Paper, IMK, Düsseldorf, November.

INTERNATIONAL MONETARY FUND (2009) "Fiscal implications of the global economic and financial crisis", Staff Position Note, SPN/09/13, June. 
INTERNATIONAL MONETARY FUND (2009) Global Financial Stability Report, October.

INTERNATIONAL MONETARY FUND (2009) World Economic Outlook, September.

INTERNATIONAL MONETARY FUND (2010) Global Financial Stability Report, Market Update, January.

KEYNES, J.M. (1936) The General Theory of Employment, Interest and Money, London, Macmillan.

KEYNES, J.M. (1937) How to Avoid a Slump, in The collected writings of John Maynard Keynes, vol. 21, Macmillan Press, 1982.

KEYNES, J.M. (1940) How to pay for the war, in The collected writings of John Maynard Keynes, vol. 9, Macmillan Press, 1972.

LAEVEN, L., and VALENCIA, F. (2008) "Systemic banking crises: A new database”, IMF Working Paper WP/08/224.

PALLEY, T.I. (2009) “America's exhausted paradigm, macroeconomic causes of the financial crisis and great recession”, New American Contract Policy Paper, New America Foundation, 22 July.

TILY, G. (2006) Keynes's theory of liquidity preference and his debt management and monetary policies, Cambridge Journal of Economics, 30, pp. 657-670.

TILY, G. (2007): Keynes's General Theory, The Rate of Interest and 'Keynesian' Economics, Palgrave Macmillan. 